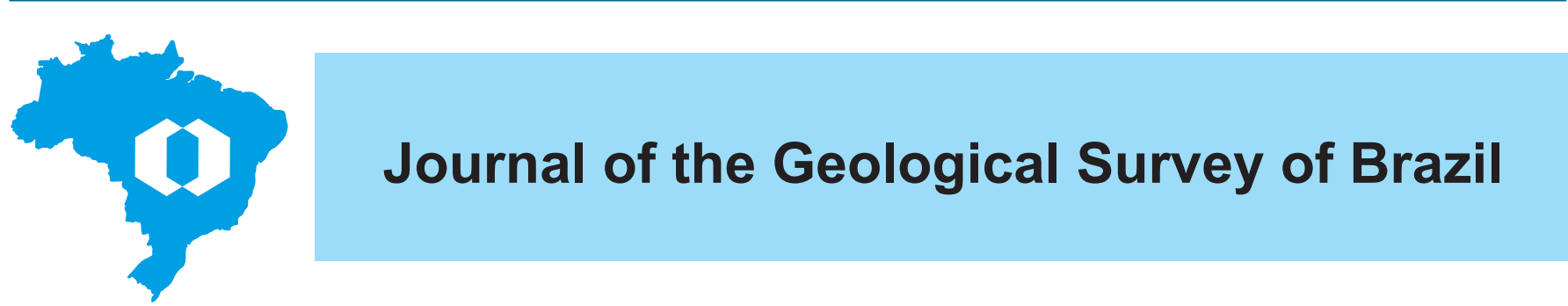

\title{
Geochemical megaprovince of fluorine and endemic fluorosis in the middle São Francisco river, Minas Gerais-Bahia, Brazil
}

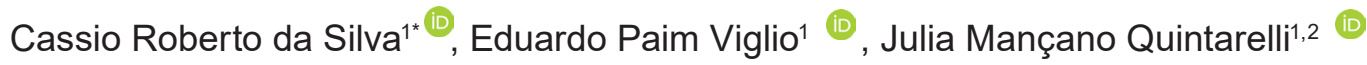 \\ ${ }^{1}$ Geological Survey of Brazil - CPRM, Av. Pasteur, 404, Urca, Rio de Janeiro-RJ, Brazil, CEP: 22290-250 \\ 2UFRJ - Universidade Federal do Rio de Janeiro. Instituto de Geociências, Av. Athos da Silveira Ramos, 274 - Cidade Universitária - Ilha do Fundão, \\ Rio de Janeiro - RJ, Brazil, CEP: 21941-916
}

\section{Abstract}

While conducting the National Program of Environmental Geochemistry and Medical Geology in the states of Minas Gerais and Bahia, the research team Geological Survey of Brazil - CPRM detected a large area with high levels of fluorine in the geochemical results of the soil, stream sediment and surface water. Fluorine levels were detected by an ion-selective electrode (stream sediment and soil samples) or by ion chromatography (water samples). In this low-density survey, the minimum, maximum and median fluorine grades found at the water samples were $0.005 \mathrm{mg} / \mathrm{L}, 7.56 \mathrm{mg} / \mathrm{L}$ and $0.05 \mathrm{mg} / \mathrm{L}$. For the soil, the samples were $15 \mathrm{mg} / \mathrm{L}, 1720 \mathrm{mg} / \mathrm{L}$ and $152 \mathrm{mg} / \mathrm{L}$, and for the stream sediment, the samples were $35 \mathrm{mg} / \mathrm{L}, 1076 \mathrm{mg} / \mathrm{L}$ and $262 \mathrm{mg} / \mathrm{L}$. The region covers 25 municipalities where studies by researchers from Federal Universities of Minas Gerais and Bahia have detected a high incidence of dental fluorosis, especially where public supply is made via deep wells in the Fissure-Karst Aquifer of the Bambuí Group. Moreover, the study area is highly favorable to the mineral deposit of fluorite and secondary $\mathrm{Pb}-\mathrm{Zn}$. Because the area is much larger $(99,000 \mathrm{~km} 2)$ than the other known fluorite provinces of Brazil (Santa Catarina is $2,000 \mathrm{~km}^{2}$ and Vale do Ribeira is $5,000 \mathrm{~km} 2$ ), the designation of Geochemical Megaprovince of Fluorine in the Middle São Francisco River, Brazil, is suggested for this region.
Article Information

Publication type: Research pape

Received 4 June 2020

Accepted 17 November 2020

Online pub. 22 December 2020

Editor: Carlos Spier

\section{Keywords:}

Medical geology,

Health,

Fluorine,

Fluorosis.

${ }^{*}$ Corresponding author

Cassio Roberto da Silva

E-mail address: cassio.silva@cprm.gov.br

\section{Introduction}

Fluorine is the main component of the minerals fluorite $\left(\mathrm{CaF}_{2}\right)$, fluorapatite $\left[\mathrm{Ca}_{5}\left(\mathrm{PO}_{4}\right)_{3} \mathrm{~F}\right]$ and cryolite $\left(\mathrm{Na}_{3} \mathrm{AlF}_{6}\right)$. Its compounds are widely used today and are part of numerous products and processes, including heat-resistant polymers, glass manufacturing, as well as in the production of uranium, in which chlorofluorocarbons (CFCs) participate in the manufacturing of uranium hexafluoride used to prepare $U_{235}$. However, it is in the health sector that this element is most relevant to the current study.

Despite its high toxicity, adequate doses of fluorine are considered to be medicinal by the World Health Organization (WHO). For instance, to help reduce the incidence of dental cavities, this element, in the form of sodium fluoride ( $\mathrm{NaF}$ ) or stannous fluoride $\left(\mathrm{SnF}_{2}\right)$, is included in toothpastes, as well as added to drinking water for public consumption, at a maximum allowed concentration of $1.4 \mathrm{mg} / \mathrm{L}$ (above this dose, it becomes a toxic agent that causes diseases such as dental and skeletal fluorosis). According to Rossi et al. (2010), sodium fluoride $(\mathrm{NaF})$ is an effective anti-osteoporotic agent to prevent fractures.
In Brazil, CONAMA resolutions nos. 357 (Brazil 2005) and 396 (Brazil 2008) and Ordinance 2914 of the Ministry of Health (Brazil 2011), which regulate the maximum amount of fluoride to be added to publicly-supplied water, establish the level of $1.4 \mathrm{mg} / \mathrm{L}$. However, calculation of toxicity takes into account, in addition to fluoride concentration, the amount of water ingested, which is calculated according to local temperature. For regions with an average temperature above $25^{\circ} \mathrm{C}$, where in general more than two liters of water are ingested per day, the optimum value is reduced to $<0.8 \mathrm{mg} / \mathrm{L}$, as in areas in the north of Minas Gerais and West of Bahia, in Brazil. According to Frazão et al. (2011), in an extensive review of the optimal amount of fluoride in publicly-supplied water, point out that temperatures in Brazilian capitals indicate that fluoride should range from 0.6 to $0.9 \mathrm{mg} /$ $\mathrm{L}$ to prevent tooth decay. A fluoride concentration of $1.5 \mathrm{mg} / \mathrm{L}$ is tolerable for consumption in Brazil, if there is no cost-effective technology for adjusting/removing its excess. The daily intake of water with fluoride at a concentration $>0.9 \mathrm{mg} / \mathrm{L}$ poses a risk to dentition among children under eight years of age, and consumers should be expressly informed of this risk.

Dental fluorosis in Brazil has been recorded and studied by Cangussu et al. (2002) in 42 municipalities in ten states 
(Alagoas, Ceará, Espírito Santo, Goiás, Minas Gerais, Paraíba, Paraná, Rio Grande do Sul, Santa Catarina, São Paulo) and the Federal District. These authors stated that the disease is a relevant problem for public oral health and that high concentrations of fluoride (min: 0.05; max: 9.46; median: $0.66 \mathrm{mg} / \mathrm{L}$ ) are common in publicly-supplied water, especially as far as groundwater is concerned.

In the northern region of the state of Minas Gerais, Velásquez et al. (2003, 2006, 2007, 2009), as well as researchers from the Federal University of Minas Gerais (UFMG) (Diniz 2006, Costa 2011, Costa et al. 2013), detected a high incidence of dental fluorosis in several municipalities, especially in those supplied by wells drilled in the Bambuí Group's Karst-Fissural Aquifer. Recently, Coutinho (2014), Gonçalves (2014), Cruz et al. (2015) and Gonçalves et al. (2018), researchers from the Federal University of Bahia (UFBA), also found incidence of dental fluorosis in the southern region of the state of Bahia in the municipalities of Santana, Serra do Ramalho and Carinhanha, which are supplied by wells drilled in the same aquifer. In both cases, the reported fluorine source is fluorite vein systems that cut the limestones of the Bambuí Group.

Being aware of the occurrences in the north of Minas Gerais, the present authors planned and performed the sampling of a low-density geochemical survey, stream sediment and surface water (one sample per $150 \mathrm{~km}^{2}$ ) and soils (one sample per $625 \mathrm{~km}^{2}$ ). They also made an analysis of fluorine in soils and sediments, in addition to fluoride in surface water, in the National Program of Environmental Geochemistry and Medical Geology (PGAGEM) of the SGB-CPRM. Importantly, soil, sediment and surface water samples were collected only on the right bank of the São Francisco River, in the state of Bahia.

In this context, it should be noted that Viglio et al. (2011) previously defined an area of approximately $200 \times 80 \mathrm{~km}$ with high levels of fluorine occurring in supply waters, surface waters, stream sediments and soils along the Verde Grande River basin in northern Minas Gerais.

In this area, there is a high potential for occurrence of fluorine deposits along its entire length. However, what has attracted the attention of researchers, mainly from UFMG and UFBA, is the incidence of dental fluorosis, which occurs as a result of high concentrations of fluoride ion in drinking water. As a consequence, there are enamel mineralization defects, whose severity directly depend on the amount ingested. In general, opaque stains can be seen on the enamel, in homologous teeth; such stains can even be yellowish or brownish regions in case of more serious effects.

This endemic is manifested the populations of 25 municipalities in both states: 10 towns in Bahia (Serra Dourada, Santana, Canápolis, Sítio do Mato, Santa Maria da Vitória, São Félix do Coribe, Serra do Ramalho, Coribe, Feira da Mata and Carinhanha) and 15 towns in Minas Gerais (Juvenília, Montalvânia, Manga, São João das Missões, Itacarambi, Januária, Jaíba, Verdelândia, Janaúba, Varzelândia, Ibiracatu, Pedras da Maria da Cruz, São Francisco, Icaraí de Minas and Montes Claros). These municipalities have a total population of 976,232 inhabitants $(208,504$ in Bahia and 767,728 in Minas Gerais). In this region, according to Misi et al. (2000), there is a noticeable potential for occurrence of Irish type (stratabound) $\mathrm{Zn}$ and $\mathrm{Pb}$ deposits (Januária-Itacarambi, Montalvânia and Serra do Ramalho).

The objective of the present study was to correlate all previous works about groundwater, expanding the original region of occurrences of high fluorine levels from the north of Minas Gerais to the south of Bahia, whose current dimensions are 550 $x 150 \mathrm{~km}$ and an area of $99,000 \mathrm{~km}^{2}$ (Figure 1). This paper will also indicate possible origins of fluorine with a view to explaining the extent of dispersion, and warnings for the municipalities in the region that have not yet registered cases of fluorosis.

\section{Geological context}

In the target region of this research, there are outcrops of Neoproterozoic pelitic-carbonate rocks of the Bambuí Group, overlying the Archean-Paleoproterozoic crystalline gneissmigmatitic basement (Misi et al. 2011).

The main rocks in the region are limestones and dolomites from the Sete Lagoas Formation, base of the Bambuí Group (metasedimentary) (Figure 1), which hosts the Karst-Fissural Aquifer System, where high fluoride concentrations occur ( $>1$ $\mathrm{mg} / \mathrm{L}$ ). This formation is overlain by a Tertiary detrital coverage and Quaternary placers. In the northwest of the study area, the Bambui Group is unconformably underlain by sandstones of the Mesozoic Urucuia Group.

Fluorite occurs in various geological environments and under different physical and chemical conditions. The most important forms of occurrence of the mineral are stratiform deposits in carbonate rocks; veins in igneous, metamorphic and sedimentary rocks and along contacts between carbonate rocks and intrusive igneous rocks. Anderson and MacQueen (2003) interpreted the $\mathrm{Pb}-\mathrm{Zn}-\mathrm{Ag}-\mathrm{F}$ mineralization of the Bambuí Group as epigenetic deposits of the MVT type (Mississippi Valley Type). The fluorite mineralization of the Bambuí Group has already been described as: epigenetics, hosting the hydrothermal fluids in zones of higher porosity and permeability (Robertson 1963); controlled by paleogeography, with diagenetic concentration (Dardenne et al. 1998); MVT with the involvement of congenital hydrothermal fluids (Dardenne and Schobbenhaus 2000 in Costa 2011).

\section{Materials and methods}

In the study area, 329 stream sediment samples were collected in drainage basins with a mean area of $150 \mathrm{~km} 2$ and 171 soil samples in a $25 \times 25 \mathrm{~km}$ grid. Two $\mathrm{kg}$ of solid materials (stream sediment and soil) were selected, sieved in the field in $20 \#$. In the laboratory, the samples were dried at $50^{\circ} \mathrm{C}$, sieved at $80 \#$, being the undersize crushed at $200 \#$, digested with aqua regia and analyzed by ICP-MS for 53 elements (Ag, Al, As, $\mathrm{Au}, \mathrm{B}, \mathrm{Ba}, \mathrm{Be}, \mathrm{Bi}, \mathrm{Ca}, \mathrm{Cd}, \mathrm{Ce}, \mathrm{Co}, \mathrm{Cr}, \mathrm{Cs}, \mathrm{Cu}, \mathrm{Fe}, \mathrm{Ga}, \mathrm{Ge}$, $\mathrm{Hf}, \mathrm{Hg}, \mathrm{In}, \mathrm{K}, \mathrm{La}, \mathrm{Li}, \mathrm{Lu}, \mathrm{Mg}, \mathrm{Mn}, \mathrm{Mo}, \mathrm{Na}, \mathrm{Nb}, \mathrm{Ni}, \mathrm{P}, \mathrm{Pb}, \mathrm{Rb}$, $\mathrm{Re}, \mathrm{S}, \mathrm{Sb}, \mathrm{Sc}, \mathrm{Se}, \mathrm{Sn}, \mathrm{Sr}, \mathrm{Ta}, \mathrm{Tb}, \mathrm{Te}, \mathrm{Th}, \mathrm{Ti}, \mathrm{U}, \mathrm{V}, \mathrm{W}, \mathrm{Y}, \mathrm{Yb}, \mathrm{Zn}$ and $Z r$ ). Fluorine was analyzed by an ion selective electrode.

The 1564 water samples were filtered in the field using a $0.45 \mu \mathrm{m}$ Millipore filter and separated into two $50 \mathrm{ml}$ polyethylene centrifuge tubes and kept refrigerated: one was acidified with 10 drops of nitric acid 1: 1, for analysis by ICPOES of 27 cations (Al, As, B, Be, Ba, Ca, Co, Cd, Cu, Cr, $\mathrm{Li}, \mathrm{Fe}, \mathrm{K}, \mathrm{Mg}, \mathrm{Mn}, \mathrm{Mo}, \mathrm{Na}, \mathrm{Ni}, \mathrm{Pb}, \mathrm{Se}, \mathrm{Si}, \mathrm{Sb}, \mathrm{Sn}, \mathrm{Sr}, \mathrm{Ti}, \mathrm{V}$ and $\mathrm{Zn}$ ). Another one was kept in natura for analysis by ion chromatography of 7 anions (fluoride, chloride, bromide, nitrite, nitrate, sulfate and phosphate).

The following physicochemical properties of waters were measured in situ: temperature, dissolved oxygen, electrical conductivity and $\mathrm{pH}$. 


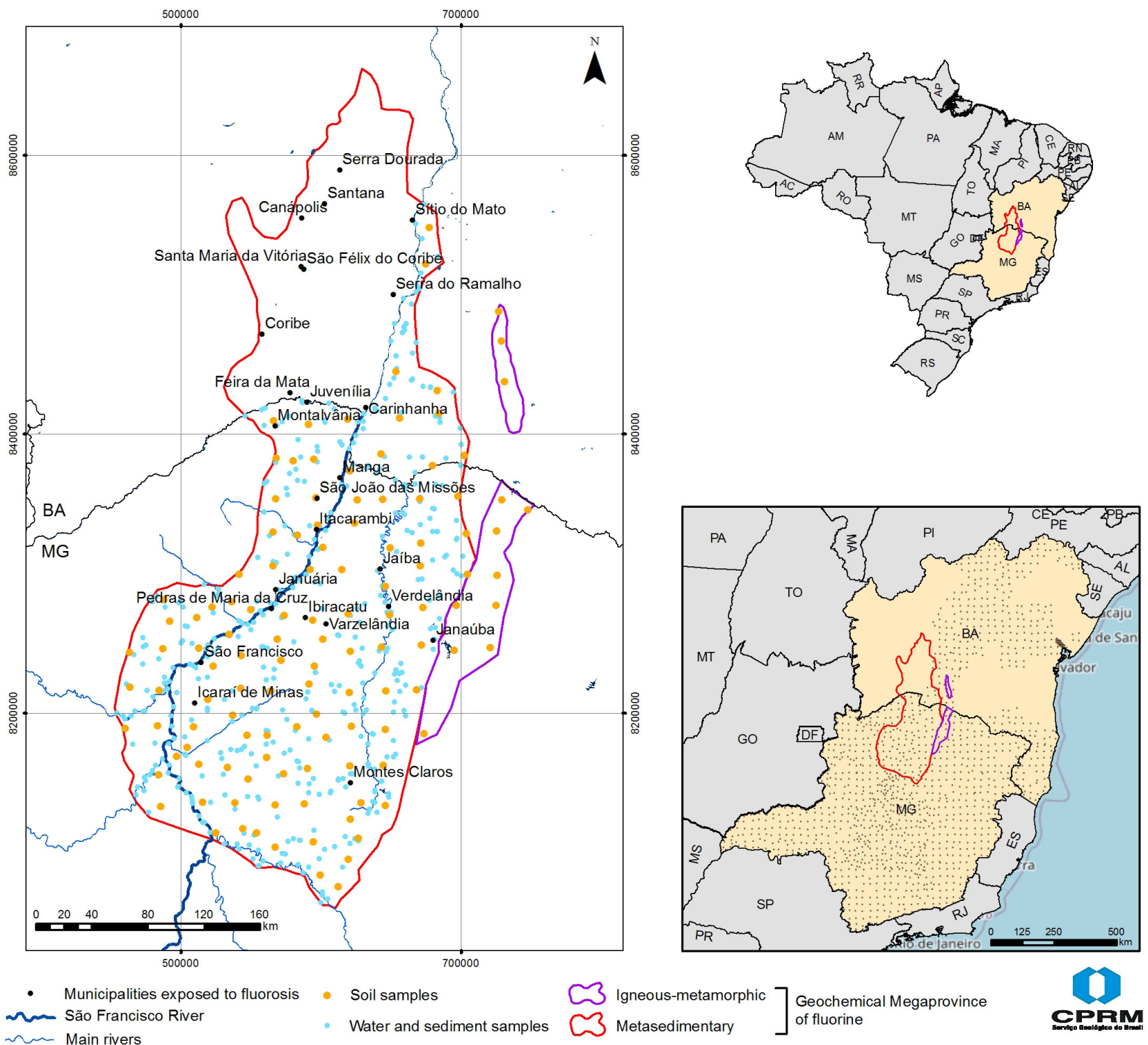

FIGURE 1. Localization of the area and samples collected from soil, water surface and stream sediment.

Statistical parameters taken from the boxplots, such as median, quartiles and IQR (Interquartile Range), were used to outline, on the maps, the surfaces of distribution of fluorine concentrations for the different sampled media, using the ArcGis 10.2 software.

After the interpretation of the analytical results, owing to the detection of high values of fluorine above the background, bibliographic research was carried out on the occurrences of this element in groundwater in several municipalities located in a similar geological context.

After data log transformation, a multivariate statistical analysis including factor analysis and principal component analysis, using Statistica software, was used to obtain mathematical evidence of high potential mineral resources in the region. In this analysis, elements are clustered by statistical similarity, and important geochemical associations are often found. This statistical approach was used to indicate regions in which soil and sediment samples (similar to those in the area that had complete data sets) were not collected. Logarithmic data were used, after elements with low representativeness were discarded, i.e., the ones whose detection limit results were under $25 \%$.

The digital surfaces (raster) that represent the distribution of concentration were generated in the ArcGis 10.6 software, through interpolation by the inverse square distances (IQD), using the same intervals of $25 \%, 50 \%, 75 \%$ and IQR of the logarithmic data.

\section{Results}

The results of the geochemical survey, carried out for fluorine in the study area, showed the occurrences of higher values than those of the background (medians: surface water $0.05 \mathrm{mg} / \mathrm{L}$; stream sediment $262 \mathrm{mg} / \mathrm{kg}$ and soil $152 \mathrm{mg} / \mathrm{kg}$ ) of the state of Minas Gerais (Table 1). 
TABLE 1 - Fluorine concentrations of surface water, soil and stream sediment samplings carried out in the northern regions of Minas Gerais and southern Bahia.

\begin{tabular}{l|c|c|c|l|l}
\hline $\begin{array}{l}\text { Sampling } \\
\text { environment }\end{array}$ & $\begin{array}{l}\text { Amount } \\
\text { of } \\
\text { samples }\end{array}$ & Minimum & Maximum & Average & Median \\
\hline Surface water & 1564 & $\begin{array}{l}0.005 \\
\mathrm{mg} / \mathrm{L}\end{array}$ & $7.56 \mathrm{mg} / \mathrm{L}$ & $0.096 \mathrm{mg} / \mathrm{L}$ & $0.05 \mathrm{mg} / \mathrm{L}$ \\
\hline $\begin{array}{l}\text { Stream } \\
\text { sediment }\end{array}$ & 329 & $35 \mathrm{mg} / \mathrm{kg}$ & $1076 \mathrm{mg} / \mathrm{kg}$ & $317 \mathrm{mg} / \mathrm{kg}$ & $262 \mathrm{mg} / \mathrm{kg}$ \\
\hline Soil & 171 & $15 \mathrm{mg} / \mathrm{kg}$ & $1720 \mathrm{mg} / \mathrm{kg}$ & $262 \mathrm{mg} / \mathrm{kg}$ & $152 \mathrm{mg} / \mathrm{kg}$ \\
\hline
\end{tabular}

TABLE 2 - Values of physicochemical properties found in surface waters and groundwater (wells).

\begin{tabular}{l|c|c|c|c}
\hline $\begin{array}{l}\text { Statistical } \\
\text { Parameters }\end{array}$ & $\mathbf{p H}$ & $\begin{array}{l}\text { Dissolved } \\
\text { Oxygen } \\
(\mathbf{m g} / \mathbf{L})\end{array}$ & $\begin{array}{l}\text { Electrical } \\
\text { Conductivity } \\
(\boldsymbol{\mu S / c m})\end{array}$ & $\begin{array}{l}\text { Temperature } \\
\left({ }^{\circ} \mathbf{C}\right)\end{array}$ \\
\hline Average & 7.0 & 5.5 & 261.3 & 24.4 \\
\hline Median & 7.0 & 5.6 & 163.7 & 24.9 \\
\hline Maximum & 9.2 & 18.1 & 1782 & 36 \\
\hline Minimum & 4.1 & 0.4 & 4.8 & 13.1 \\
\hline
\end{tabular}

Table 2 shows the results of the on-site measurements of the physicochemical parameters of the waters $-\mathrm{pH}$, dissolved oxygen (DO), electrical conductivity and temperature.

The area was divided by lithology into two main compartments, a metasedimentary and an igneousmetamorphic one (Figures 2, 4 and 5). Most of the area consists of metasedimentary rocks of the Bambuí Group. To the east of this area, there are two small areas made up of granitic-dioritic rocks, called igneous-metamorphic areas, which were not the subject of this study.

Figures 2, 4, and 5 show the spatial distribution of fluoride in surface and groundwater (data from SGB-CPRM; Diniz 2006), sediments and soils in the study region (data from SGB-CPRM) (Figures 2, 4 and 5). It should be noted that in the northwestern portion in the state of Bahia, on the left side of the São Francisco River, stream sediments and soils were not analyzed for fluorine. Although such environment is favorable to the existence of $\mathrm{Pb}-\mathrm{Zn}$ mineralization, no values above background for these elements were found (Table 3 ).

A comparison of the distribution of fluoride content (Figure 2) in surface water and groundwater (wells) in the study area, showed that fluoride content was higher in underground water than in surface water in the state of Minas Gerais. Importantly, fluoride content in groundwater, in the study area, was 2.75 times higher than the average for the state of Minas Gerais (Figure 3), which is indicative of an anomalous region for fluoride.

TABLE 3 - Comparison of $\mathrm{Pb}$ and $\mathrm{Zn}$ values found in the study region and in the entire state of Minas Gerais. Source: Viglio and Cunha (2018).

\begin{tabular}{|c|c|c|c|c|}
\hline \multirow{2}{*}{$\begin{array}{l}\text { Sampling } \\
\text { environment }\end{array}$} & \multicolumn{2}{|l|}{$\mathrm{Pb}$} & \multicolumn{2}{|l|}{ Zn } \\
\hline & $\begin{array}{l}\text { Studied } \\
\text { area }\end{array}$ & $\begin{array}{l}\text { Minas } \\
\text { Gerais }\end{array}$ & $\begin{array}{l}\text { Studied } \\
\text { area }\end{array}$ & $\begin{array}{l}\text { Minas } \\
\text { Gerais }\end{array}$ \\
\hline Surface water & $0.001 \mathrm{mg} / \mathrm{L}$ & $0.001 \mathrm{mg} / \mathrm{L}$ & $0.02 \mathrm{mg} / \mathrm{L}$ & $0.005 \mathrm{mg} / \mathrm{L}$ \\
\hline Sediment & $13.1 \mathrm{mg} / \mathrm{kg}$ & $12.3 \mathrm{mg} / \mathrm{kg}$ & $22 \mathrm{mg} / \mathrm{kg}$ & $27 \mathrm{mg} / \mathrm{kg}$ \\
\hline Soil & $11.1 \mathrm{mg} / \mathrm{kg}$ & $12.2 \mathrm{mg} / \mathrm{kg}$ & $10 \mathrm{mg} / \mathrm{kg}$ & $11 \mathrm{mg} / \mathrm{kg}$ \\
\hline
\end{tabular}

The results for distribution of fluorine in soils (Figure 4) show values above the median - $152 \mathrm{mg} / \mathrm{kg}$ - in almost the entire extension (80\%) of the area in Minas Gerais, particularly in the southeast (Montes Claros, Janaúba, Varzelândia).

The results for distribution of fluorine in the stream sediments (Figure 5), show values above the median (262 $\mathrm{mg} / \mathrm{kg}$ ) only in the southeast portion of the study area, on the right side of the São Francisco River (Montes Claros, Icaraí de Minas to Manga). In the other sampled regions, on the left side of the São Francisco River, in Minas Gerais, Bahia and in the igneous-metamorphic bodies, the values were below the median.

As shown by the results found in the multivariate statistical analysis, fluorine in sediments is associated with $\mathrm{Ag}, \mathrm{Mn}$ and $\mathrm{Ca}$ in factor 4, encompassing a large part of the proposed province with intermediate and high correlation values, where high concentrations of these four elements occur (Figure 6).

In the soil samples, fluorine appeared in factor 7 associated with $\mathrm{Hg}$, As and $\mathrm{Pb}$, predominantly in the Verde Grande River basin (Figure 7).

In surface waters, the best correlation appears in factor 1 , where fluoride is associated with other anions, which shows a good outline along the Verde Grande River basin, on the left margin of the São Francisco River, in Bahia, and in the 2 adjacent igneous-metamorphic sub-provinces (Figure 8).

\section{Discussions}

In the surface waters of the study area, fluoride concentration showed an average of $0.096 \mathrm{mg} / \mathrm{L}$ and a median of $0.05 \mathrm{mg} / \mathrm{L}$; therefore, it is higher than the data in the table mentioned for most of the world's rivers.

Fluoride is generally found in groundwater in greater quantities than in surface water (Battalha and Parlatore 1977 in Diniz 2006), and this has indeed occurred in this study. In natural waters, fluoride varies widely, with generally lower levels in rain and surface waters and higher rates in groundwater (Table 4).

The natural concentration of fluoride in tubular wells that exploit groundwater depends on geological and chemical factors, physical characteristics of the water supply area, soil consistency, rock porosity, $\mathrm{pH}$ and water temperature, presence of other elements (such as $\mathrm{Fe}, \mathrm{Al}, \mathrm{Ca}$ and $\mathrm{B}$ ) and well depth (Livingstone 1963, Worl et al. 1973, World Health Organization 1984).

Compared to the study area, fluorine concentrations in natural waters and sediments in the municipality of Cerro Azul, state of Paraná (PR), where the fluorite deposits of Volta Grande and Mato Preto are located, were lower than the results found in the study area, i.e., in water - 0.005 $7.56 \mathrm{mg} / \mathrm{L}$ - and higher in sediments - 35-1076 mg/kg (Andreazzini et al 2006), respectively. In Tanguá (RJ), the water values were higher than those in the study area and, in Itambaracá (PR), the median is higher (Panagoulias and Silva Filho 2005) (Table 5).

Velásquez et al. (2006) analyzed fluoride concentrations in waters of 78 wells drilled in the Bambuí Aquifer, in the municipality of São Francisco, northern Minas Gerais, which ranged from zero to $3.9 \mathrm{mg} / \mathrm{L}$, with 13 wells $(17 \%)$ exceeding the local recommended limit $(0.8 \mathrm{mg} / \mathrm{L}$ for human consumption). It is worth mentioning that the municipalities of Santana (Bahia) and São Francisco (Minas Gerais) 


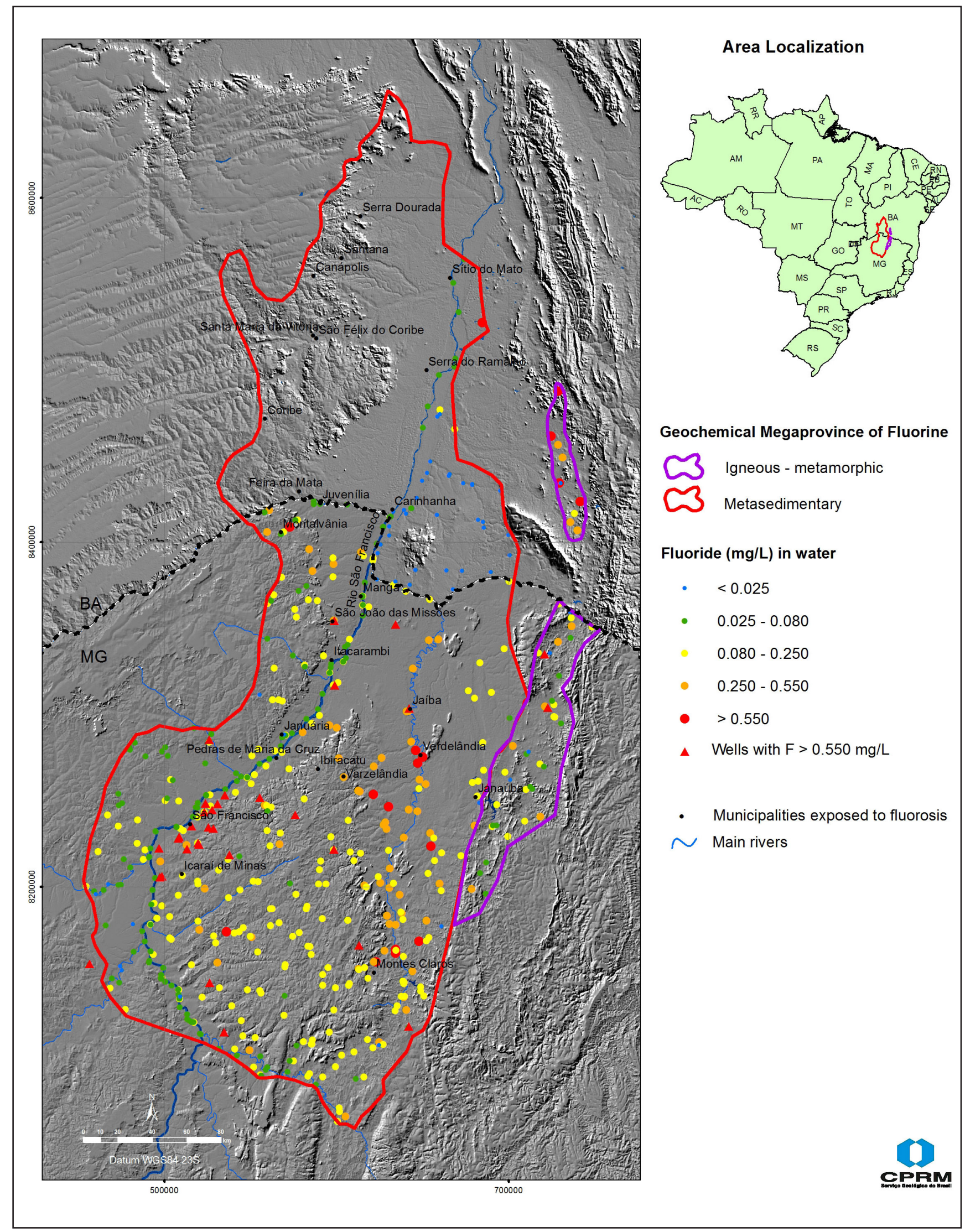

FIGURE 2. Results for fluoride distribution in surface and underground waters. 


\section{Fluoride Concentration (mg/L)}

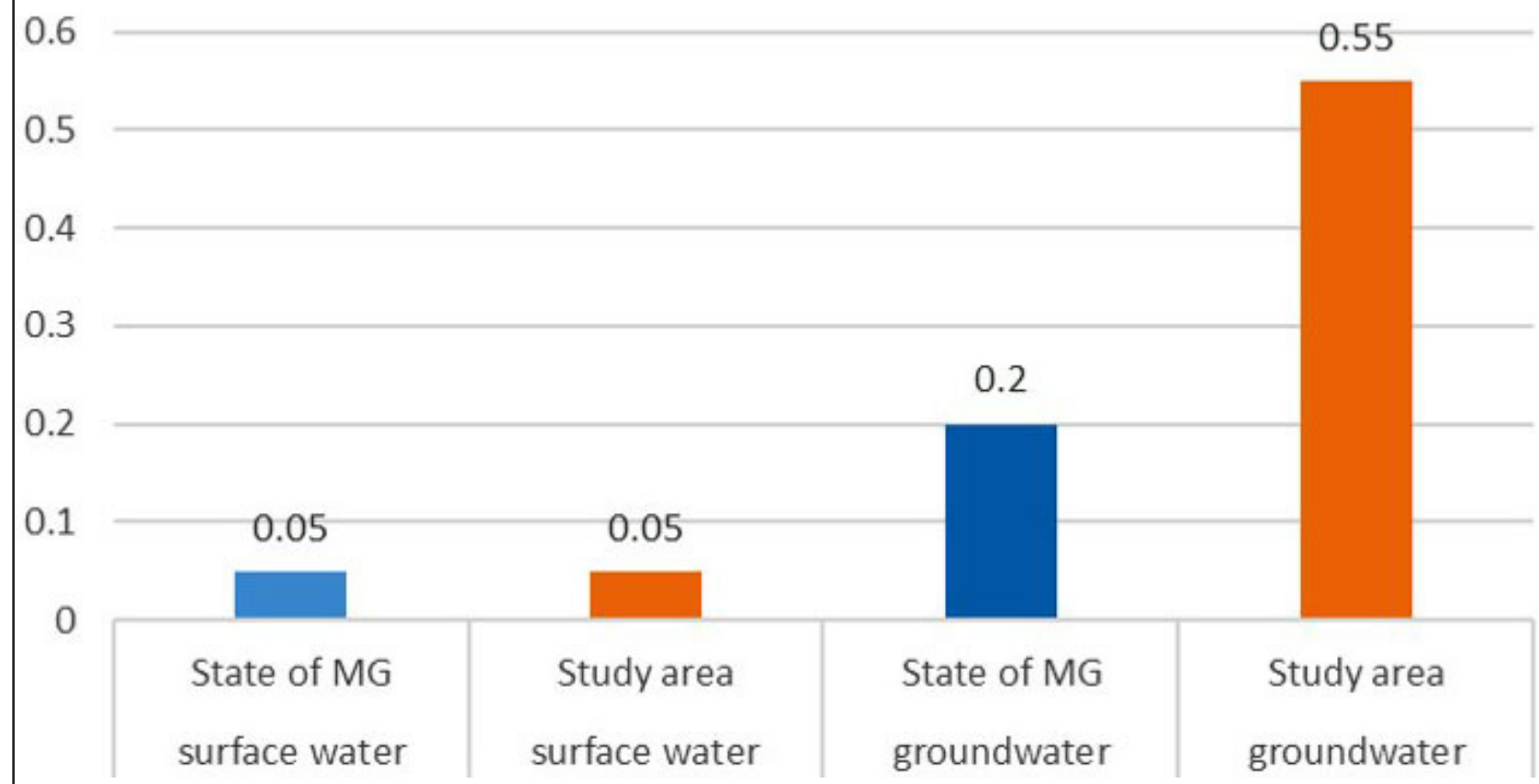

FIGURE 3. Comparison of the medians ( $\mathrm{mg} / \mathrm{L}$ of Fluor) of surface and groundwater in the study region, with surface and groundwater in the state of Minas Gerais.

have similar geological, climatic and pluviometric contexts. According to Velásquez et al. (2006) and Cruz et al. (2015), the two municipalities represent endemic areas of dental fluorosis. Therefore, the fluorine-health relationship and fluoride values in the waters of these endemic areas require identification of sources and understanding of local hydrogeochemistry (Gonçalves et al. 2020).

In a later study, Velásquez et al. (2007) mentioned that, embedded in the carbonate sequence of the Bambuí Group and deposited in a sub-coastal marine environment below the base level of the waves and tidal currents, discontinuous fluorite mineralization occurs sparsely distributed in a range from Januária (MG) to Brejo Velho (BA) region. Those authors reported that 155 well waters samples from 25 municipalities had an average fluoride concentration of $0.75 \mathrm{mg} / \mathrm{L}$, with $18 \%$ above $0.8 \mathrm{mg} / \mathrm{L}$ and $44 \%$ above $1.5 \mathrm{mg} / \mathrm{L}$ and, in Verdelândia, up to $11.0 \mathrm{mg} / \mathrm{L}$. They also mentioned that 9 samples of cisterns showed fluoride content higher than the regional groundwater background in northern Minas Gerais $(0.4 \mathrm{mg} / \mathrm{L})$, ranging from 0.11 to $0.71 \mathrm{mg} / \mathrm{L}$, with an average $0.33 \mathrm{mg} / \mathrm{L}$. According to Diniz (2006), the fluoride background of groundwater in the state of Minas Gerais is $0.25 \mathrm{mg} / \mathrm{L}$.

Gonçalves et al. (2018) also investigated the basic hydrogeochemistry of the Bambuí Aquifer in five municipalities - Santana, São Félix do Coribe, Serra do Ramalho, Coribe and Carinhanha - in western Bahia, with an emphasis on fluoride in 61 tubular wells (average depth of $90 \mathrm{~m}$ ). The $\mathrm{pH}$ values ranged between 6.87 and 8.93 , with predominantly alkaline conditions. Fluoride concentrations exceeded the limit recommended locally $(0.8 \mathrm{mg} / \mathrm{L})$ by $25 \%$ of the wells, reaching $6.20 \mathrm{mg} / \mathrm{L}$, with an average of $0.96 \mathrm{mg} / \mathrm{L}$. According to Gonçalves et al. (2020), toxic fluoride levels detected in 15 samples in the municipality of Santana (BA) presented a risk of dental fluorosis (47\%), a risk of skeletal fluorosis (20\%) and deformities in the knees and hips or disabling fluorosis (20\%). Fluoride values in these groundwaters are usually higher than those in Minas Gerais.

Table 6 shows that the fluoride values obtained in the groundwater of municipalities in the north of Minas Gerais by Velásquez et al. (2006) as well as those found by Gonçalves et al. (2018) for municipalities in the south of Bahia are larger than those affected for the state of Minas Gerais, in general.

Small local fluorite vein systems are not enough to explain such extensive fluorine dispersion in surface waters, sediments and soils. Perhaps the metapelites enriched in phosphates with fluorapatite of the Serra da Saudade Formation, mapped as the base of the Jaíba hill (Iglesias and Uhlein 2008), could also be considered as a source of fluorine, as mentioned by Viglio et al. (2011).

Megaprovinces of fluorine are common worldwide, with occurrences in countries such as the United States of America, Argentina, Africa, England, France, India and China (Figure 9). It is estimated that more than 200 million people in the world are consuming groundwater with fluoride concentrations higher than the value allowed by World Health Organization (2008), which is $1.5 \mathrm{mg} / \mathrm{L}$.

The fluorine-health relationship is of global importance, because the ingestion of natural waters with toxic levels of fluoride represents a relevant route of exposure to health risks (Komati and Figueiredo 2013, Raju 2017, Abiye et al. 2018, Kumar et al. 2018, Rashid et al. 2018). 


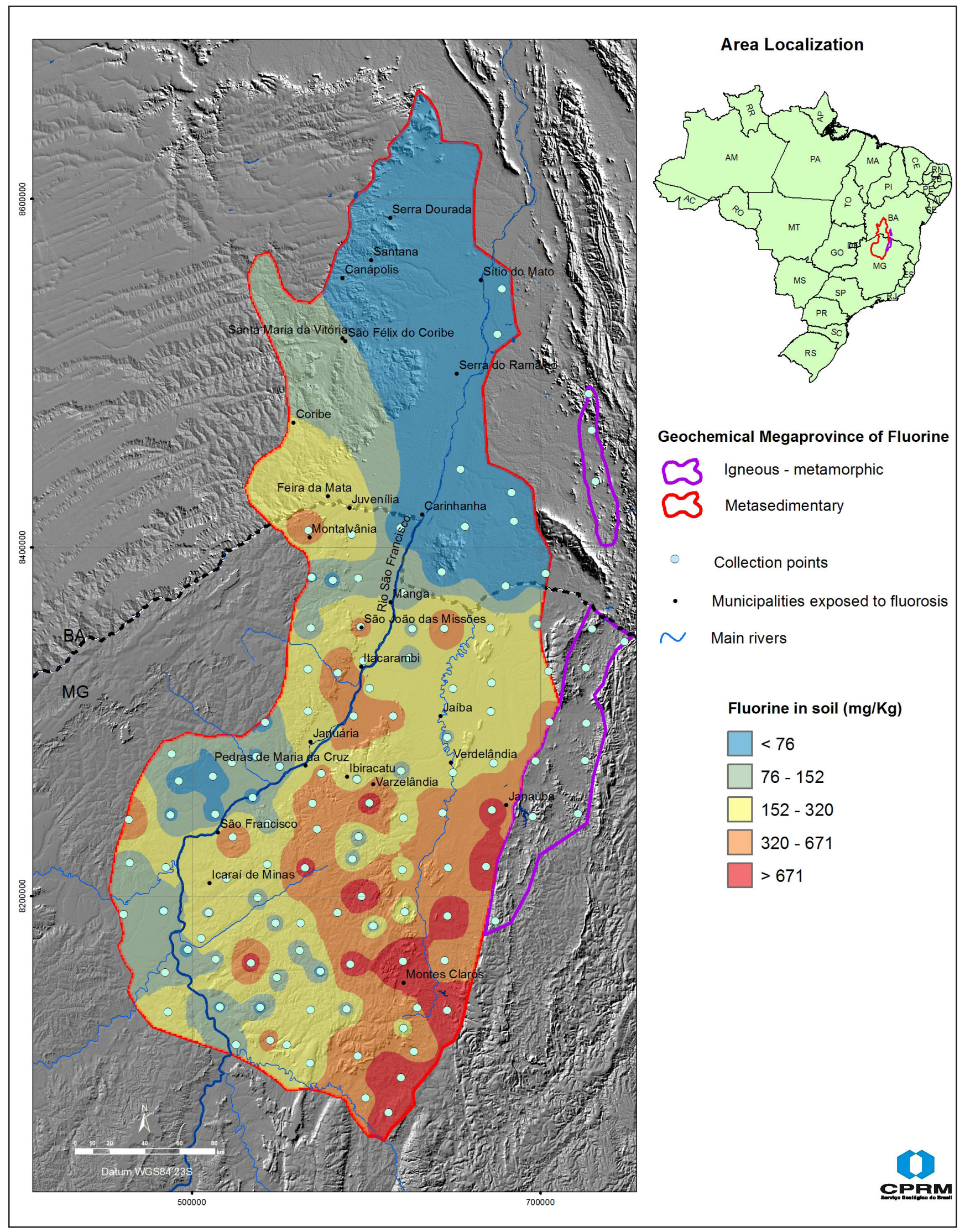

FIGURE 4. Results for distribution of fluorine in soils. 


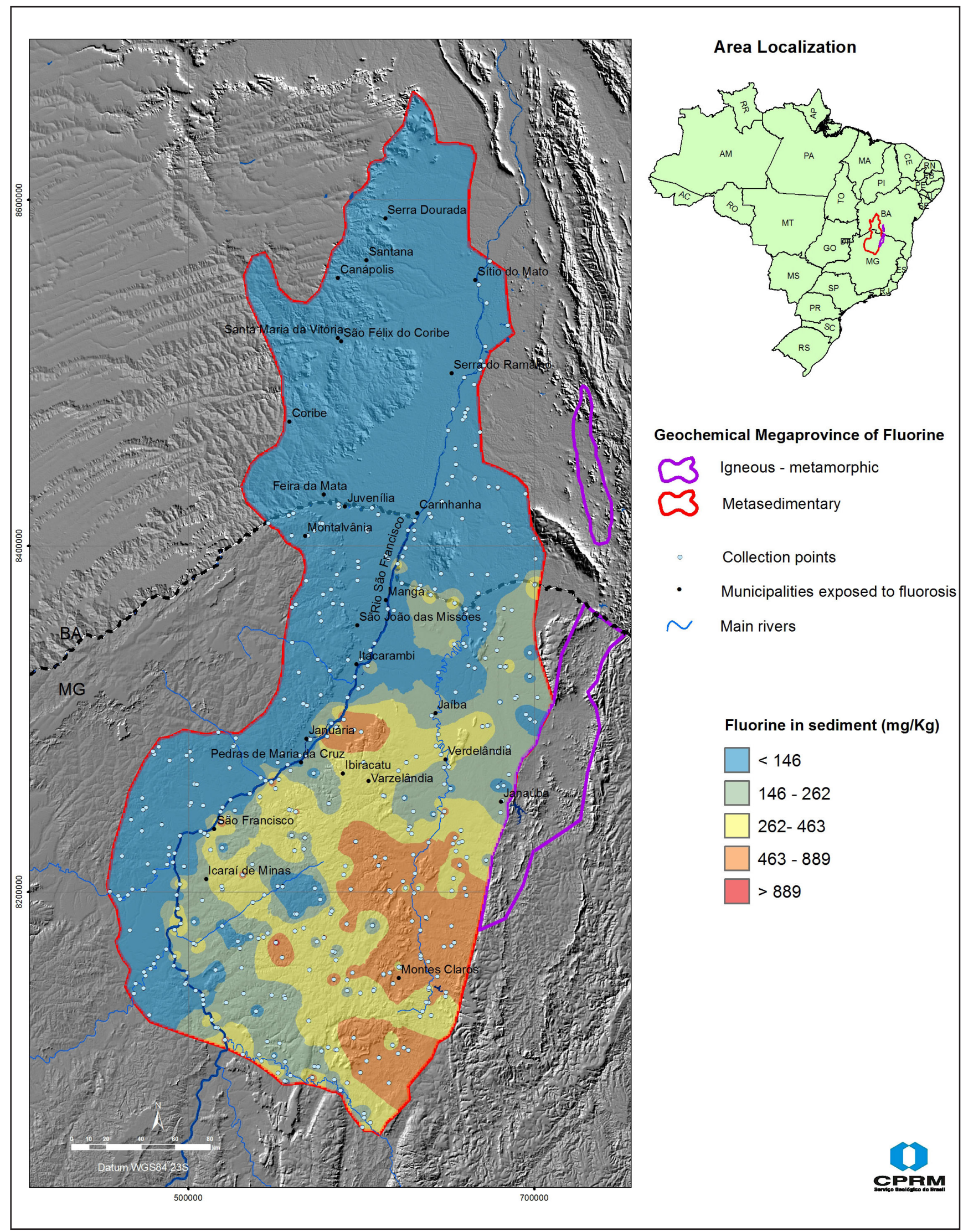

FIGURE 5. Results for distribution of fluorine in stream sediments. 


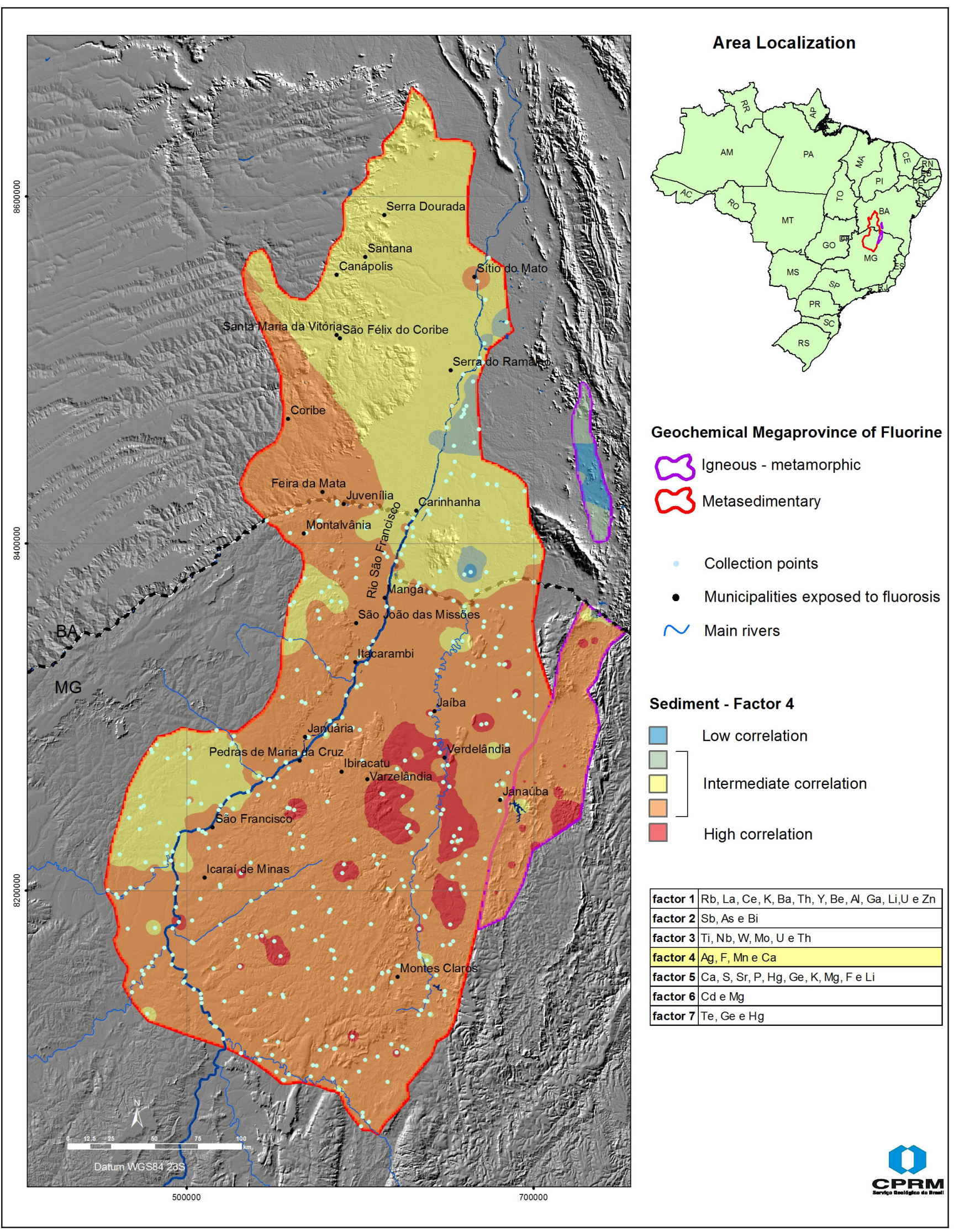

FIGURE 6. Distribution of elements associated with factor 4 in stream sediments. 


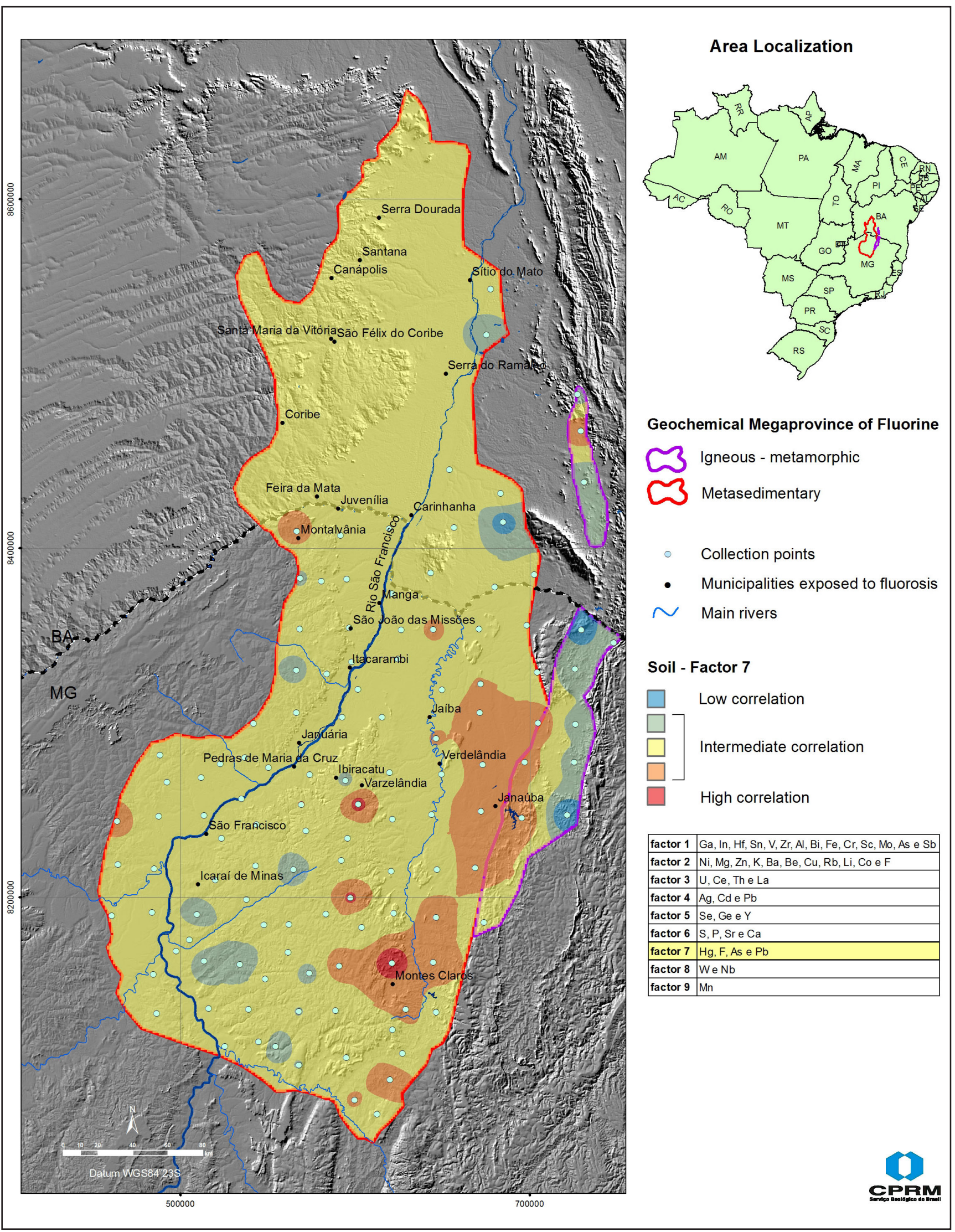

FIGURE 7. Distribution of elements associated with factor 7 in soils. 


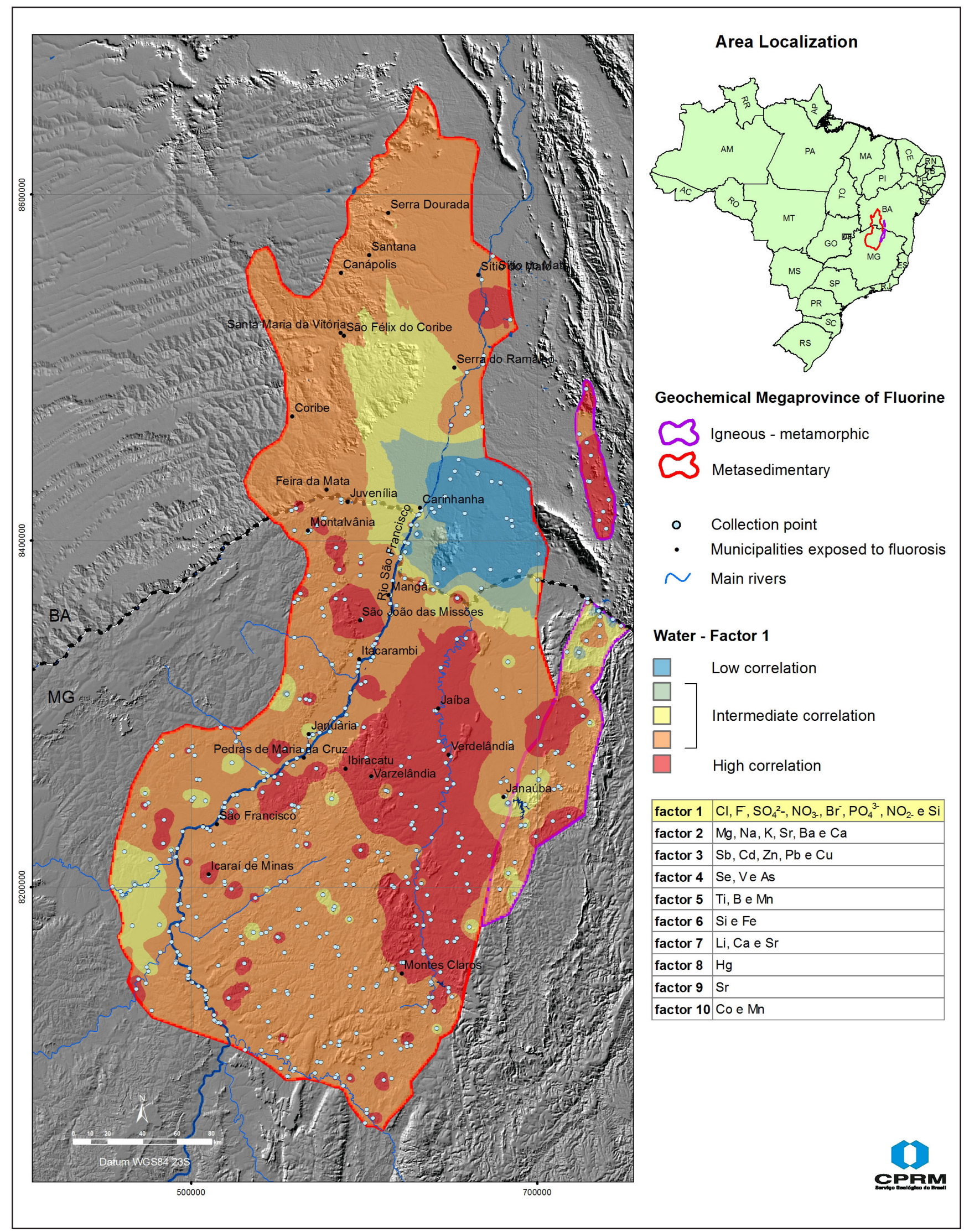

FIGURE 8. Distribution of elements associated with factor 1 in surface waters. 
TABLE 4 - Range of fluoride ion values for natural waters.

\begin{tabular}{l|c}
\hline Unpolluted waters & Fluoride Concentration $(\mathbf{m g} / \mathbf{L})$ \\
\hline Surface waters & \\
\hline Most of the world rivers & $0.10-0.40$ \\
\hline Groundwaters $^{1}$ & $0.01-0.02$ \\
\hline Oceans $^{1}$ & $0.10-3.00$ \\
\hline Precipitations $^{2}$ & $0.30-1.30$ \\
\hline
\end{tabular}

Source: 'Hem 1985; '2Edmunds and Smedley 2004 (in Gonçalves 2014).

TABLE 5 - Values of fluorine and fluoride ions in natural and fluorite mining areas

\begin{tabular}{l|l|c|c}
\hline \multirow{2}{*}{ Municipalities } & $\begin{array}{l}\text { Fluorine } \\
\text { mines }\end{array}$ & $\begin{array}{l}\text { Fluoride (mg/L) } \\
\text { in surface waters }\end{array}$ & $\begin{array}{l}\text { Fluorine } \\
\text { n sediments (ppm) }\end{array}$ \\
\hline \multirow{2}{*}{ Cerro Azul (PR) } & Volta Grande & $0.07-2.54$ & $330-1300$ \\
\cline { 2 - 4 } & Mato Preto & 6.0 & - \\
\hline Tanguá (RJ) & Tanguá & 6.0 & - \\
\hline Itambaracá (PR) & Itambaracá & 0.25 & \\
\hline
\end{tabular}

Source: 'Andreazzini et al. 2006; '2Panagoulias and Silva Filho 2006; 'icht 1996. PR: Paraná state, RJ: Rio de Janeiro state

\section{Conclusion}

The high levels of fluorine (above the regional background) and the association with other elements by factor analysis in surface waters, stream sediments and soils suggest that the region has a high potential for fluorine occurrences.

The fluorine district of Santa Catarina, the fluorine district of Ribeira (PR/SP), and the one of this study, whose areas are equivalent to $2,000 \mathrm{~km}^{2}, 5,000 \mathrm{~km}^{2}$ and $99,000 \mathrm{~km}^{2}$, respectively. Therefore, in a comparison for size, this region can be appropriately referred to as a megaprovince.

Thus, for the area addressed in this study, the name "Geochemical Megaprovince of Fluorine of the Middle São Francisco River, MG-BA, Brazil" is suggested.

There are high concentrations of fluorine in the physical environment, with the presence of a large number of wells drilled for public supply, animal feed and irrigation in a region with a semiarid climate, which suffers constant droughts. This situation can compromise the public health system with increasing incidence of dental fluorosis cases, which

TABLE 6 - Statistical summary of fluoride levels in $\mathrm{mg} / \mathrm{L}$ in groundwater in municipalities in the south of the state of Bahia and in the north of the state of Minas Gerais and of the entire state of Minas Gerais.

\begin{tabular}{|l|c|c|c|c|c|c|}
\hline Municipalities & Amount of Samples & Minimum & Maximum & Average & Median & CV (\%) \\
\hline Santana (BA) & 41 & 0.05 & 9.46 & 1.41 & 0.54 & 135 \\
\hline Canápolis (BA) $^{1}$ & 21 & 0.15 & 7.0 & 1.02 & 0.66 & 141 \\
\hline Santa Maria da Vitória (BA) & 39 & 0.02 & 3.5 & 0.73 & 0.53 & 89 \\
\hline Serra Dourada (BA) & 28 & 0.17 & 5.20 & 1.43 & 0.95 & 87 \\
\hline Serra do Ramalho (BA) & 8 & 0.11 & 1.95 & 0.52 & 0.13 & 127 \\
\hline Sítio do Mato (BA) & 10 & 0.16 & 6.12 & 2.39 & 1.46 & 96 \\
\hline São Francisco (MG) & 78 & 0 & 3.9 & 0.45 & - & - \\
\hline Varzelândia (MG) & - & 0.2 & 0.92 & - & - & - \\
\hline State of Minas Gerais* & 1065 & 0.05 & 4.25 & 0.3 & 0.2 & 153 \\
\hline
\end{tabular}

Source: ${ }^{1}$ Gonçalves et al. 2018, 2020; ${ }^{2}$ Velásquez et al. 2006.

* Data calculated by the authors, based on the Atlas of the State of Minas Gerais, which is under preparation BA: Bahia state, MG: Minas Gerais state

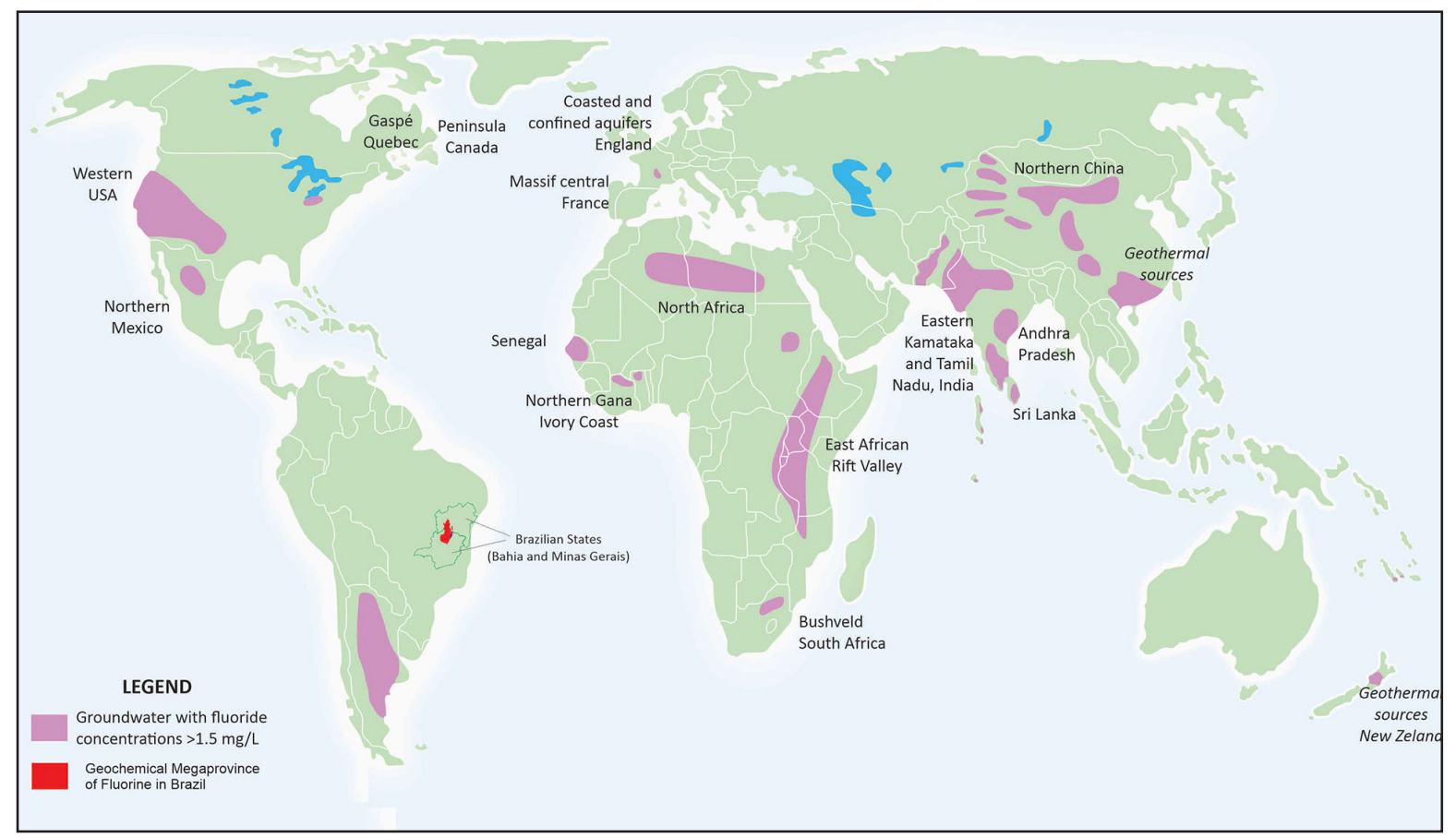

FIGURE 9. Worldwide distribution of large fluorine provinces in groundwater, with concentrations above $1.5 \mathrm{mg} / \mathrm{L}$.

Modified from Edmunds and Smedley 2013. 
can progress to more severe cases of skeletal fluorosis. In this megaprovince, with 25 municipalities, there are 976,232 inhabitants exposed to fluoride.

Therefore, the municipal, state and federal authorities need to be aware of this fact with a view to advising the population of further districts from the municipal headquarters about the best way to be use water with a high concentration of fluorine. Therefore, the dissemination of the present work will be an important educational tool as well as a facilitator of socioeconomic management.

\section{Acknowledgements}

To Jose Luiz Marmos, Jose Carlos Garcia Ferreira, Eduardo Marques, Jussara Amorim, Claudia Santos, Sueli Araujo and Liz Matos for discussions and revision of the text.

\section{References}

Abiye T., Bybee, Leshomo J. 2018. Fluoride concentrations in the arid Namaqualand and the Waterberg groundwater, South Africa: Understanding the controls of mobilization through hydrogeochemical and environmental isotopic approaches. Groundwater for Sustainable Development, v. 6, p. 112-120. https://doi.org/10.1016/j.gsd.2017.12.004

Andreazzini M.J., Figueiredo B.R., Licht O.A.B. 2006. Comportamento geoquímico do flúor em águas e sedimentos fluviais da região de Cerro Azul, estado do Paraná, Brasil. Revista Brasileira de Geociências, 36 , 336-46. DOI: 10.25249/0375-7536.2006362336346

Anderson G.M., MacQueen R.W. 2003. Mississipi Valley type leadzinc deposits. In: Bizzi L.A., Schobbenhauss C., Vidotti R.M., Gonçalves J.H. Geologia, tectônica e recursos minerais do Brasil: texto, mapas e SIG. Brasília, CPRM.

Brazil. Conselho Nacional do Meio Ambiente. 2005. Resolução n 357, de 17 de março de 2005. Dispõe sobre a classificação dos corpos de água e diretrizes ambientais para o seu enquadramento, bem como estabelece as condições e padrões de lançamento de efluentes e dá outras providências. Brasília, MMA, $23 \mathrm{p}$.

Brazil. Conselho Nacional do Meio Ambiente. 2008. Resolução n 396, de 3 de abril de 2008. Dispõe sobre a classificação e diretrizes ambientais para o enquadramento das águas subterrâneas e dá outras providências. Brasília, MMA, $11 \mathrm{p}$.

Brazil. Ministério da Saúde. 2011. Portaria MS 2.914, de 12 de dezembro de 2011. Dispõe sobre os procedimentos de controle e de vigilância da qualidade da água para consumo humano e seu padrão de potabilidade. Brasília, MS, 2011.

Cangussu M.C.T., Narvai P.C., Castellanos Fernandez R., Djehizian V. 2002. A fluorose dentária no Brasil: uma revisão crítica. Cadernos de Saúde Pública, 18, 7-15. https://doi.org/10.1590/S0102$\underline{311 \times 2002000100002}$

Costa D.A. 2011. Controle litoestrutural e estratigráfico na hidrogeoquímica e nas concentrações de fluoreto no sistema aquífero cárstico-fissural do grupo Bambuí, norte de Minas Gerais. Dissertação de Mestrado, Instituto de Geociências, Universidade Federal de Minas Gerais, Belo Horizonte, 138 p. http://hdl.handle.net/1843/MPBB-8JNPEM

Costa S.M., Abreu M.H.N.G., Vargas A.M.D., Vasconcelos M., Ferreira E., Castilho L.S. 2013. Cárie dentária e fluorose endêmica em distritos rurais de Minas Gerais, Brasil. Revista Brasileira de Epidemiologia, 16, 1021-8. http://dx.doi.org/10.1590/S1415-790X2013000400022

Coutinho C.A.M. 2014. A fluorose dentária na região cárstica do município de Santana-BA: definição de áreas de risco para consumo humano das águas subterrâneas com base nos dados hidroquímicos e epidemiológicos. Dissertação de Mestrado, Instituto de Geociências, Universidade Federal da Bahia, Salvador, 109 p. http://repositorio. ufba.br/ri/handle/ri/21533

Cruz M.J.M., Coutinho C.A.M., Gonçalves M.V.P. 2015. The dental fluorosis on Santana karst region, Bahia state, Brazil. Journal of Geography and Earth Sciences, 3, 51-67. http://dx.doi.org/10.15640/ jges.v3n2a3

Dardenne M.A., Freitas-Silva F.H., Souza J.C.F., Campos J.E.G. 1998. Evolução tectono-ssedimentar do grupo Vazante no contexto da faixa de dobramentos Brasília. In: Congresso Brasileiro de Geologia,
40, 26. Available on line at: http://sbg.sitepessoal.com/anais digitalizados/1998-BELO\%20HORIZONTE/CBG1998.pdf (accessed on 20 November 2020)

Diniz L.G. 2006. O flúor nas águas subterrâneas do estado de Minas Gerais. MSc Dissertation, Instituto de Geociências, Universidade Federal de Minas Gerais, Belo Horizonte, 178 p. http://hdl.handle. net/1843/MPBB-6VQGQ7

Edmunds W.M., Smedley P.L. 2013. Fluoride in natural waters. In: Selinus O., Alloway B., Centeno J.A., Finkelman R.B., Fuge R., Lindh U., Smedley P.L. (eds.). Essentials of Medical Geology, p. 311-36. DOl: 10.1007/978-94-007-4375-5 13

Frazão P., Peres M.A., Cury J.A. 2011. Qualidade da água para consumo humano e concentração de fluoreto. Revista de Saúde Publica, 45(5):964-973

Gonçalves M.V.P. 2014. Flúor em águas subterrâneas da área cárstica do sudoeste da Bahia (Brasil). PhD Thesis, Instituto de Geociências, Universidade Federal da Bahia, Salvador, 194 p. http://repositorio. ufba.br/ri/handle/ri/21531

Gonçalves M.V.P., Cruz M.J.M., Santos R.A., Ramos Junior A.B.S., Coutinho C.A.M. 2018. Flúor na água do aquífero Bambuí no oeste da Bahia (Brasil). Brazilian Journal of Aquatic Science and Technology, 22, 10-21. https://doi.org/10.14210/bjast.v22n1.9654

Gonçalves M.V.P., Santos R.A., Coutinho C.A.M., Cruz M.J.M. 2020. Fluoride levels in the groundwaters and prevalence of dental fluorosis in the municipality of Santana, in region karstic of West Bahia Brazil. In: Groundwater Hydrology. IntechOpen, 24 p. DOI: 10.5772/ intechopen.85007

Hem J.D. 1985. Study and Interpretation of the Chemical Characteristics of Natural Water. 3rd Edition, US Geological Survey Water-Supply Paper 2254, University of Virginia, Charlottesville, 263 p. Available online at: https://pubs.usgs.gov/wsp/wsp2254/\#pdf (accessed on 20 November 2020).

Iglesias M., Uhlein A. 2008. Estratigrafía do grupo Bambuí na serra do Jaíba, norte de Minas Gerais. Geonomos, 16, 21-27. https://doi. org/10.18285/geonomos.v16i1.90

Kumar S., Venkatesh A. S., Singh R., Udayabhanu G., Saha D. 2018. Geochemical signatures and isotopic systematics constraining dynamics of fluoride contamination in groundwater across Jamui district, Indo-Gangetic alluvial plains, India. Chemosphere, 205, 493505. https://doi.org/10.1016/i.chemosphere.2018.04.116

Komati S.H., Figueiredo B.R. 2013. Flúor em água e prevalência de fluorose em Amparo (SP). Geociências (São Paulo), 32, 3, p. 547559. Available on line at: http://ppegeo.igc.usp.br/index.php/GEOSP/ article/view/7298 (accessed on 17 June 2020)

Livingstone D.A. 1963. Chemical composition of rivers and lakes. In: Fleischer, M. Data of Geochemistry. Washington, Geological Survey. Professional Paper, 440, 1-64. Available on line at: https://pubs.usgs. gov/pp/0440g/report.pdf (accessed on 17 June 2020)

Misi A., lyer S.S., Coelho C.E.S., Tassinari C.C.G., Franca-Rocha W.J.S., Gomes A.S.R., Cunha I.A., Toulkeridis T., Sanchesa A.L. 2000. A metallogenic evolution model for the lead-zinc deposits of the meso and neoproterozoic sedimentary basins of the São Francisco craton, Bahia and Minas Gerais, Brazil. Revista Brasileira de Geociências, 30, 302-305. Available on line at: http://ppegeo.igc.usp.br/index.php/rbg/ article/view/10821 (accessed on 17 November 2020)

Misi A., Kaufman A.J., Azmy K., Dardenne M.A., Sial A.N., Oliveira T.F. 2011. Neoproterozoic successions of the São Francisco craton, Brazil: The Bambuí, Una, Vazante and Vaza Barris/Miaba groups and their glaciogenic deposits. Geological Society, London, Memoirs, 36, 50922. https://doi.org/10.1144/M36.48

Panagoulias T.I., Silva Filho E.V. 2006. Estudo hidrogeoquímico do flúor nas águas subterrâneas das bacias dos rios Casseribu, Macacu e São João, estado do Rio de Janeiro. In: Silva C.R., Figueiredo B.R., De Capitani E.M., Cunha F.G. (eds.). Geologia Médica no Brasil: efeitos dos materiais e fatores geológicos na saúde humana, animal e meio ambiente, Rio de Janeiro, CPRM, p. 126-9. http://rigeo.cprm.gov.br/jspui/handle/doc/1211

Raju N.J. 2017. Prevalence of fluorosis in the fluoride enriched groundwater in semi-arid parts of eastern India: Geochemistry and health implications. Quaternary International, 443, Part B, p. 265-278. https://doi.org/10.1016/j.quaint.2016.05.028

Rashid A., Guan D. X., Farooqi A., Khan S., Zahir S., Jehan S., Khattak S. A., Khan M.S., Khan R. 2018. Fluoride prevalence in groundwater around a fluorite mining area in the flood plain of the River Swat, Pakistan. Science of the Total Environment, 635, p.203-215. https:// doi.org/10.1016/j.scitotenv.2018.04.064 
Robertson J.F. 1963. Geology of the lead-zinc deposits in the município of Januária, state of Minas Gerais, Brazil. U.S. Geological Survey, Bulletin 1110-B, 110. https://doi.org/10.3133/b1110B

Rossi A.C.; Freire A. R.; Dornelles R. C. M. 2010. Osteoporose: considerações sobre terapêuticas atuais e metabolismo ósseo. IDJ. International Journal of Dentistry, 9. Available on line at: https:// periodicos.ufpe.br/revistas/dentistry/article/view/14079 (accessed on 20 November 2018)

Velásquez L.N.M., Fantinel L.M., Costa W.D., Uhlein A., Ferreira E.F.E. Castilho L.S., Paixão H.H. 2003. Origem do flúor na água subterrânea e sua relação com os casos de fluorose dental no município de São Francisco, Minas Gerais. Belo Horizonte, Fapemig (Relatório CRA 294/99), $138 p$

Velásquez L.N.M., Fantinel L.M., Ferreira E.F.E., Castilho L.S.; Uhlein A., Vargas A.M.D., Aranha P.R.A. 2006. Fluorose dentária e anomalias de flúor na água subterrânea no município de São Francisco, Minas Gerais. In: Silva C.R., Figueiredo B.R., De Capitani E.M., Cunha F.G. (eds.). Geologia Médica no Brasil: efeitos dos materiais e fatores geológicos na saúde humana, animal e meio ambiente. Rio de Janeiro, CPRM, p. 110-17. http://rigeo.cprm.gov.br/jspui/handle/ doc/1211

Velásquez L.N.M., Fantinel L.M., Fleming P.M., Minardi P.S.P., Rodrigues P.C.H., Nacif W.F.N., Viola Z.G.G., Silva S.M., Soares L.C., Costa D.A.,
Pereira C., Freitas A.M. 2009. Processos geradores de concentração anômala de fluoreto na água subterrânea em região semiárida: estudo de caso em aquífero cárstico-fissural do grupo Bambuí nos municípios de Verdelândia, Varzelândia e Jaíba, Minas Gerais. Belo Horizonte, Fapemig (Relatório EDT 83032/06), 236 p.

Velásquez L.N.M., Uhlein A., Fantinel L.M., Vargas A.M.D., Ferreira E.F., Castilho L.S., Aranha P.R.A. 2007. Investigação hidrogeológica do flúor em aquíferos carbonáticos do médio São Francisco, MG, e epidemiologia da fluorose dentária associada. Relatório CNPq, 130 p.

Viglio E.P., Cunha F.G. 2018. O atlas geoquímico da bacia do São Francisco: Minas Gerais. Belo Horizonte, CPRM. http://rigeo.cprm. gov.br/jspui/handle/doc/20939

Viglio E.P., Velásquez L.N.M., Baggio H. 2011. Prospecção geoquímica de baixa densidade de flúor em bacias da margem direita do rio São Francisco - norte de Minas Gerais. In: Congresso Brasileiro de Geologia, 13.

World Health Organization. 1984. Environmental health criteria 36: fluorine and fluorides. Genebra. http://hdl.handle.net/20.500.11822/29338

World Health Organization. 2008. Guidelines for drinking-water quality. v.1. Recommendations. Geneva. Available on line at: https://www.who. int/water_sanitation health/publications/gdwq3rev/en/ (accessed on 20 November 2018)

Worl R. G., Vanalstine R. E. Shawe D. R. 1973. Fluorine. p. 223-235. 